\title{
PENGEMBANGAN MULTIMEDIA PEMBELAJARAN BAHASA INGGRIS MATERI FUNCTIONAL TEXT BAGI SISWA SMPN 3 KALASAN
}

\author{
Siti Niah, Christina Ismaniati \\ Universitas Abdurrab Pekanbaru Riau, Universitas Negeri Yogyakarta \\ st_niah@yahoo.co.id, ismaniati_fipuny@yahoo.com
}

\begin{abstract}
Abstrak
Penelitian ini bertujuan untuk menghasilkan produk multimedia pembelajaran Bahasa Inggris materi functional text dengan pendekatan komunikatif yang layak bagi siswa kelas VII SMP N 3 Kalasan Yogyakarta, serta mengetahui keefektifan produk multimedia pembelajaran Bahasa Inggris dengan pendekatan komunikatif yang dihasilkan. Penelitian ini merupakan penelitian dan pengembangan (research and development, R\&D). Hasil penelitian ini adalah sebagai berikut: (1) menghasilkan produk multimedia pembelajaran Bahasa Inggris materi functional text dengan pendekatan komunikatif yang layak bagi siswa kelas VII SMP yang dikemas dalam sebuah CD. Produk yang dihasilkan layak digunakan untuk pembelajaran berdasarkan validasi ahli materi, ahli media, dan siswa. (2) Produk multimedia pembelajaran Bahasa Inggris dengan pendekatan komunikatif bagi siswa kelas VII SMP N 3 Kalasan ini efektif untuk digunakan sebagai media pembelajaran materi functional text. Peningkatan skor postes siswa setelah menggunakan produk multimedia pembelajaran bahasa Inggris sebesar $64.5 \%$ dengan nilai ( $\mathrm{N}$-gain) 0.74 dan ketuntasan belajar siswa (KKM) sebesar $93.5 \%$. Sedangkan kelas sebelum menggunakan produk multimedia pembelajaran bahasa Inggris memiliki nilai ( $\mathrm{N}$-gain) siswa sebesar 0.33 dan ketuntasan belajar siswa (KKM) sebesar $29.03 \%$.
\end{abstract}

Kata kunci: Multimedia Bahasa Inggris, Pendekatan Komunikatif

\section{DEVELOPING ENGLISH LEARNING MULTIMEDIA FOR THE TOPIC OF FUNCTIONAL TEXT STUDENTS OF SMPN 3 KALASAN}

\author{
Siti Niah, Christina Ismaniati \\ Universitas Abdurrab Pekanbaru Riau, Universitas Negeri Yogyakarta \\ st_niah@yahoo.co.id, ismaniati_fipuny@yahoo.com
}

\begin{abstract}
This study aims to produce an English learning multimedia product for the topic of functional text which is appropriate employing the communicative approach for Grade VII students of SMPN 3 Kalasan, Yogyakarta, and to investigate the effectiveness of the developed English learning multimedia product. This was a research and development $(R \mathcal{E} D)$. The results of the study are as follows: (1) producing an English learning multimedia product for the topic of functional text which is approriate employing the communicative approach for Grade VII students of SMP which is packed in a CD. The appropriateness product to be used for learning based on the validation by the material expert, media expert, and beta test. (2) The developed product that employing communicative approach is effective to be used as an English learning multimedia of the topic functional text. The increasing students' score that have used English learning multimedia product is $64.5 \%$ with a gain score of 0.74 and mastery learning students $93.5 \%$. While a class before using the product with the gain score 0.33 and $29.03 \%$ students' mastery learning.
\end{abstract}

Keywords: English Multimedia, Communicative Approach 


\section{Pendahuluan}

Bahasa Inggris merupakan salah satu mata pelajaran di SMP yang terdapat dalam kurikulum 2013. Mata pelajaran ini wajib dipelajari oleh siswa karena perannya berfungsi sebagai media komunikasi, dan salah satu materi yang menekankan komunikasi adalah materi functional text. Tujuan pembelajaran dalam kurikulum 2013 menekankan pada tiga aspek kompetensi inti yaitu kompetensi pengetahuan, keterampilan, dan sikap. Kompetensi tersebut harus dikuasai oleh siswa secara holistik. Materi functional text ini pada kenyataannya merupakan materi yang masih sulit dipelajari oleh siswa karena sulitnya mengenali jenis fitur teks dan isi dari informasi yang disampaikan.

Kesulitan yang dihadapi oleh siswa merupakan kendala utama dalam proses pembelajaran materi ini. Kendala yang dihadapi dalam pembelajaran materi functional text diantaranya adalah kurang tepatnya pemilihan metode/pendekatan yang digunakan dan tidak tersedianya media untuk mengajarkan materi ini. Metode yang digunakan selama ini masih terfokus pada guru yang lebih banyak berperan menjelaskan materi dan belum melibatkan siswa secara maksimal dalam proses pembelajarannya, serta hanya mengandalkan buku pegangan dari Kemendikbud 2013 sebagai sumber belajar utama. Hal tersebut menyebabkan sulitnya siswa meamahami functional text.

Peran metode/pendekatan dan multimedia sangat penting dalam proses pembelajaran bahasa Inggris khususnya functional text. Jika kedua hal tersebut masih menjadi kendala utama dalam pembelajaran, maka kualitas pembelajaran akan menurun sehingga tujuan pembelajaran dan Kriteria Ketuntasan Minimal (KKM) siswa tidak tercapai. Berkenaan dengan hal itu perlu adanya pertimbangan dalam pemilihan metode/pendekatan yang cocok dan penggunaan multimedia/media berbasis komputer untuk memudahkan siswa dalam memahami Bahasa Inggris dengan efektif dan efisien.

Salah satu metode/pendekatan yang dapat digunakan untuk meningkatkan pemahaman siswa terhadap materi yang dipelajari yaitu dengan menggunakan metode/pendekatan komunikatif. Djiwandono (2011, pp.17-18) menjelaskan penyelenggaraan pembelajaran bahasa didasari pada pendekatan, dan pendekatan yang digunakan adalah pendekatan tradisional, diskret, integratif, pragmatik, dan komunikatif. Penelitian ini menggunakan salah satu pendekatan yang disebutkan di atas yaitu pendekatan komunikatif untuk mengajarkan functional text, karena pendekatan ini sesuai dengan situasi nyata untuk pembelajaran bahasa Inggris, baik secara reseptif maupun secara produktif.

Sedangkan Iskandarwassid \& Sunendar (2013, p.56) menyatakan pentingnya pendekatan komunikatif dalam mengajarkan bahasa Inggris khususnya materi functional text karena fungsi bahasa sebagai alat komunikasi menjadi semakin tegas. Pendekatan komunikatif digunakan dalam pengajaran materi ini karena pendekatan ini tidak saja membahas tentang kaidahkaidah tata bahasa, tetapi lebih kepada pemahaman siswa terhadap karakteristik materi functional text secara langsung yang ada dalam kehidupan sehari-hari sesuai dengan tema functional text yang dimuat dalam pengembangan ini yaitu meliputi notice, warning, caution, dan announcement. Sementara itu karakteristik functional text ini sendiri yaitu siswa harus mengenali fitur teks dan jenis teks, diantaranya adalah judul, teks bercetak tebal, teks dicetak miring, grafik, ilustrasi, simbol, dan lainnya.

Selain pemilihan metode/pendekatan yang tepat untuk mengajarkan functional text, penggunaan media sebagai alat untuk memudahkan siswa dalam pembelajaran juga sangat penting, seperti yang disebutkan oleh Supardi (2011, p.136) yaitu pembelajaran berbasis komputer tidak hanya membuat proses pembelajaran lebih efisien tetapi juga penggunaan media 
dapat membantu siswa memahami materi ajar secara mendalam dan utuh. Dipilihnya multimedia sebagai media yang dapat membantu siswa dalam memahami functional text karena dapat menyatukan beberapa unsur media untuk menyampaikan materi seperti yang dikemukakan oleh Ivers \& Barron (2010, p.2) multimedia is the use of several media to present information, combinations may include text, graphics, animation, pictures and sound. Menurut pendapat tersebut, unsur multimedia yang terdiri dari teks, grafik, animasi, gambar, dan suara dalam pembelajaran diharapkan dapat memenuhi kebutuhan belajar siswa yang memiliki kemampuan kognitif yang berbeda.

Alasan lain dipilihnya multimedia didasarkan pada hasil penelitian yang dilakukan oleh Najjar (1996) yang menyebutkan bahwa orang dapat mengingat 10\% dari apa yang mereka baca, 20\% dari apa yang mereka dengar, 30\% dari apa yang mereka lihat, dan $50 \%$ dari apa yang mereka dengar dan lihat. Selain itu Gafur (2012, p.105) menjelaskan digunakannya multimedia sebagai media pembelajaran adalah dalam proses komunikasi, informasi masuk ke dalam kesadaran manusia melalui panca indera dan jika dalam proses informasi digunakan lebih dari satu media yang dapat menyentuh kelima indera manusia maka proses informasi akan lebih efektif. Dengan demikian pembelajaran menggunakan multimedia menjadi lebih efektif dan dapat menjadi salah satu solusi pemecahan masalah pembelajaran.

Pengembangan produk multimedia yang memenuhi aspek-aspek pembelajaran serta pemilihan media pembelajaran yang tepat guna dalam pembelajaran telah dibahas dalam salah satu bidang ilmu yaitu bidang instructional technology. Definisi Teknologi Pembelajaran yang dirumuskan oleh Association for Educational Communications And Technology (AECT) (2004, p.3) "Educational technology is the study and ethical practice of facilitating learning and improving performance by creating, using, and managing appropriate technological processes and resources". Definisi teknologi pembelajaran tahun 2004 ini mengandung maksud bahwa teknologi pembelajaran mempunyai peran untuk memfasilitasi pembelajaran dan meningkatkan kinerja dengan cara menciptakan, menggunakan atau memanfaatkan dan mengelola proses dan sumbersumber teknologi yang tepat.

Salah satu bidang garapan dalam Teknologi Pembelajaran yaitu menciptakan bahan ajar yang tepat guna sesuai dengan kebutuhan. Dalam kaitannya dengan pengembangan produk multimedia pembelajaran berdasarkan definisi di atas, peran teknologi pembelajaran adalah untuk memfasilitasi dan meningkatkan kinerja agar tujuan pembelajaran dapat tercapai dengan cara "creating, using, and managing" yaitu dengan menciptakan, menggunakan dan mengontrol bahan ajar yang dikembangkan agar sesuai dengan fungsinya dan dapat memberi kemudahan dalam belajar.

Berdasarkan bidang garapan teknologi pembelajaran di atas, maka cakupan Teknologi Pembelajaran salah satunya adalah menciptakan atau mengembangkan, menggunakan serta mengontrol bahan ajar yang tepat guna sesuai dengan kebutuhan siswa. Dalam pembelajaran di sekolah, guru hendaknya selalu berinovasi dalam menciptakan pembelajaran yang inovatif melalui pengembangan bahan ajar sebagai media yang dapat digunakan dalam proses pembelajaran. Upaya pengembangan bahan ajar sebagai media dalam proses pembelajaran penting untuk dilakukan guna mewujudkan pembelajaran yang efektif dan efisien. Sehingga kompetensi yang harus dicapai oleh siswa dapat dikuasai.

Pengembangan produk multimedia pembelajaran dengan pendekatan komunikatif merupakan solusi alternatif sebagai pemanfaatan sumber belajar yang dapat digunakan oleh siswa sebagai media dalam pembelajaran yang dapat memberikan solusi pemecahan masalah pembelajaran. Sajian produk multimedia pembelajaran ini sebagai bentuk pemanfaatan media pembelajaran yang tepat guna sesuai dengan 
kebutuhan siswa karena didesain berdasarkan konsep instruksional.

Berdasarkan latar belakang, maka rumusan masalah dalam penelitian ini yaitu: (1) bagaimana menghasilkan produk multimedia pembelajaran Bahasa Inggris materi functional text dengan pendekatan komunikatif yang layak bagi siswa kelas VII SMP? dan (2) bagaimanakah keefektifan produk multimedia pembelajaran bahasa Inggris materi functional text dengan pendekatan komunikatif bagi siswa kelas VII SMP yang dihasilkan? Sedangkan tujuan dari penelitian ini yaitu: (1) menghasilkan produk multimedia pembelajaran Bahasa Inggris materi functional text bagi siswa kelas VII SMP serta (2) mengetahui bagaimanakah keefektifan produk multimedia pembelajaran bahasa Inggris materi functional text bagi siswa kelas VII SMP yang dihasilkan.

\section{Metode Penelitian}

Jenis Penelitian

Pengembangan produk multimedia pembelajaran dengan pendekatan komunikatif termasuk Research and Development ( $R$ \& D). Penelitian ini bertujuan untuk menghasilkan produk multimedia pembelajaran berupa CD pembelajaran untuk mata pelajaran bahasa Inggris siswa kelas VII SMP.

\section{Model Pengembangan}

Model prosedural yang dipakai mengacu pada langkah-langkah yang telah dikembangkan oleh Alessi \& Trollip (2001, p.410) yaitu: planning, design, dan development dengan atribut pengembangannya standards, ongoing evaluation, dan project management.

Prosedur Pengembangan

Prosedur pengembangan produk multimedia pembelajaran dalam penelitian ini dapat dijelaskan sebagaimana disajikan pada Gambar 1.

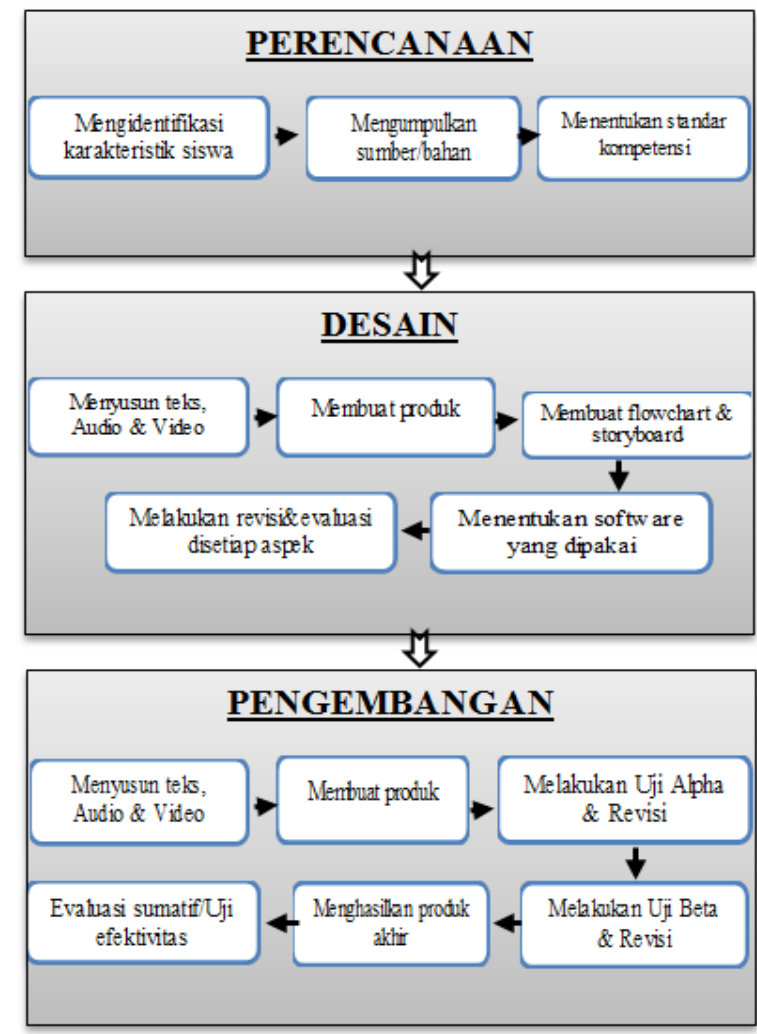

Gambar 1. Bagan Prosedur Pengembangan dari Alessi \& Trollip (2001, pp.411-413)

\section{Desain Uji Coba}

Uji coba produk sebagai bagian dari tahap pengembangan dilakukan dengan dua tahap yaitu uji beta dan uji efektivitas. Uji beta dilakukan kepada siswa kelas VII SMP untuk mengetahui pendapat siswa mengenai kualitas produk media yang dihasilkan. Hasil uji beta ini kemudian dianalisis dan dijadikan masukan untuk perbaikan produk ahir. Uji efektivitas dilakukan kepada siswa untuk mengetahui peningkatan hasil belajar setelah menggunakan produk media pembelajaran.

\section{Subjek Coba}

Subjek penelitian untuk uji coba produk yang dikembangkan dalam penelitian ini adalah siswa kelas VII berjumlah 31 siswa SMP Negeri 3 Kalasan Sleman Yogyakarta tahun ajaran 2013/2014. 
Teknik dan Instrumen Pengumpulan Data

Teknik yang dilakukan untuk menghimpun data selama proses pengembangan produk multimedia pembelajaran Bahasa Inggris ini adalah menggunakan teknik wawancara, angket, dan tes. Instrumen yang digunakan untuk mengumpulkan data berupa instrumen penilaian untuk menilai produk yang telah dikembangkan dari aspek instruksional, aspek materi, aspek pemrograman, dan aspek tampilan. Instrumen diberikan kepada ahli materi, ahli media, dan siswa.

Adapun penjelasan dari masingmasing instrumen tersebut pertama: Wawancara, yaitu kegiatan ini dilakukan untuk mengumpulkan data dari siswa dan guru sehubungan dengan analisis kebutuhan yang diperlukan sebagai pengembangan produk multimedia pembelajaran.

Kedua: Angket yaitu digunakan untuk mengetahui ketepatan rancangan produk sebagai program multimedia pembelajaran dari ahli materi, ahli media dan siswa. Angket ini digunakan untuk pengumpulan data kuantitatif. Instrumen diberikan kepada ahli materi untuk mendapatkan data tentang kelayakan program yang dikembangkan ditinjau dari aspek pembelajaran dan aspek isi materi. Hasil dari penilaian dijadikan sebagai dasar untuk melaksanakan revisi produk multimedia pembelajaran.

Instrumen selanjutnya diberikan kepada ahli media untuk mendapatkan data tentang kelayakan program yang dikembangkan ditinjau dari aspek tampilan dan aspek pemograman/kegrafisan. Hasil dari pinilaian tersebut dijadikan bahan untuk merevisi dan penyempurnaan produk pengembangan.

Instrumen angket berikutnya diberikan kepada siswa untuk memperoleh data tentang kualitas program yang dihasilkan dilihat dari sudut pandang siswa ketika melakukan uji beta/uji produk, dan hasil dari penilaian ini dijadikan bahan untuk merevisi produk serta pengembangan produk ahir. Semua instrumen untuk lembar evaluasi menggunakan skala interval 5 dengan jenis pertanyaan yang sesuai dengan masing-masing posisi sebagai penilai. Ketiga: tes, yaitu berupa soal pretes dan postes pilihan ganda sebanyak 20 soal yang digunakan untuk mengetahui efektivitas atau pengaruh produk multimedia pembelajaran terhadap kemampuan siswa memahami bahasa Inggris materi functional text setelah menggunakan produk multimedia pembelajaran ahasa Inggris.

\section{Validitas Instrumen}

Validitas instrumen dalam penelitian berupa pembuatan kisi-kisi kuesioner/angket untuk ahli materi, ahli media, dan siswa/pengguna, serta pembuatan kisi-kisi soal pretes dan postes diberikan kepada seorang dosen ahli pembelajaran yang ditunjuk sebagai validator untuk memvalidasi instrumen, kemudian hasil dari validasi tersebut dianalisis dan dilakukan perbaikan jika terdapat kesalahan dalam penyusunan instrumen. Setelah instrumen tersebut dinyatakan valid oleh validator selanjutnya instrumen dapat digunakan untuk melakukan penelitian.

\section{Teknik Analisis Data}

Teknik analisis data kelayakan produk multimedia pembelajaran menggunakan skala likert. Skor yang diperoleh kemudian dikonversikan menjadi nilai dengan skala 5, yaitu membagi nilai standar menjadi lima skala atau lima kualifikasi. Skala 5 dalam teknik statistik penelitian dan pengembangan ini yaitu $\mathrm{A}=$ sangat baik, angka $\mathrm{B}=$ baik, angka $\mathrm{C}=$ cukup baik, angka $\mathrm{D}=$ kurang baik, dan $\mathrm{E}=$ sangat kurang. Untuk mengetahui kualitas produk hasil pengembangan baik dari aspek materi maupun aspek media, serta siswa terhadap produk pengembangan, maka dari data yang semula berupa skor, diubah menjadi data kualitatif dengan skala lima. Adapun acuan pengubahan skor menjadi skala lima yang disajikan pada Tabel 1. 
Tabel 1. Konversi Skor Skala 5

\begin{tabular}{ccc}
\hline Rumus & Perhitungan & Kriteria \\
\hline $\mathrm{X}>\mathrm{Xi}+1,8 \mathrm{SBi}$ & $\mathrm{X}>4,21$ & Sangat baik \\
$\mathrm{Xi}+0.6 \mathrm{SBi}<\mathrm{X} \leq \mathrm{Xi}+1,8 \mathrm{SBi}$ & $3,40<\mathrm{X} \leq 4,21$ & Baik \\
$\mathrm{Xi}+0.6 \mathrm{SBi}<\mathrm{X} \leq \mathrm{Xi}+0,6 \mathrm{SBi}$ & $2,60<\mathrm{X} \leq 3,40$ & Cukup \\
$\mathrm{Xi}-1,8 \mathrm{SBi}<\mathrm{X} \leq \mathrm{Xi}-0,6 \mathrm{SBi}$ & $1,79<\mathrm{X} \leq 2,60$ & Kurang \\
$\mathrm{X}>\mathrm{Xi}-1,8 \mathrm{SBi}$ & $\mathrm{X} \leq 1,79$ & Sangat kurang \\
\hline
\end{tabular}

Sedangkan teknik analisis data untuk melihat keefektifan penggunaan produk hasil pengembangan dengan melihat nilai gain score dan persentase kelulusan siswa. Nilai gain score sebelum dan sesudah menggunakan produk multimedia pembelajaran bertujuan untuk mengetahui efektivitas produk pembelajaran yang berupa tingkat penguasaan materi functional text yang diwujudkan dalam skor tes hasil belajar siswa. Pembelajaran dengan menggunakan produk hasil pengembangan diperhitungkan dengan rumus $N$-gain yang ditentukan berdasarkan rata-rata gain skor yang dinormalisasi (g) yaitu perbandingan dari skor gain. Rata-rata gain yang dinormalisasi (N-gain) (Hake, 1998, p.2) dinyatakan oleh persamaan sebagai berikut:

keterangan:

$$
g=\frac{S \text { post }-S \text { pre }}{\text { S maks }- \text { S pre }}
$$

g : Nilai gain yang dinormalisasi

$S$ post : Rata-rata Skor Postes

$S$ pre : Rata-rata Skor Pretes

S maks: Skor Maksimal

Nilai tersebut kemudian diinterpretasikan ke dalam tabel klasifikasi nilai Gain (Hake, 1998,p.3) yang disajikan pada Tabel 2.

Tabel 2. Interpretasi Nilai Gain

\begin{tabular}{cc}
\hline Nilai $(\mathrm{g})$ & Klasifikasi \\
\hline$(\mathrm{N}$-gain $) \geq 0,7$ & Tinggi \\
$0,7>(\mathrm{N}$-gain $) \geq 0,3$ & Sedang \\
$(\mathrm{N}$-gain $)<0,3$ & Rendah \\
\hline
\end{tabular}

\section{Hasil Penelitian dan Pembahasan}

Pengembangan produk multimedia pembelajaran dengan pendekatan komuni- katif ini dikembangkan melalui tahap perencanaan penelitian. Perencanaan penelitian dilakukan dengan melaksanakan prasurvei ke tempat penelitian yang bertujuan untuk menjaring informasi mengenai karakteristik siswa, sumber belajar yang digunakan, strategi pembelajaran yang diterapkan, serta penggunaan komputer sebagai media pembelajaran. Hal tersebut dilakukan guna mengetahui pembelajaran Bahsa Inggris yang telah berlangsung di sekolah SMPN 3 Kalasan selama ini.

Data yang diperoleh selama peneliti melakukan pra survei tersebut dapat diketahui bahwa: (1) karakteristik siswa SMP N 3 Kalasan memiliki bermacam jenis. Masing-masing siswa memberikan masukan tentang keinginan mereka dalam belajar bahasa Inggris diantaranya ingin belajar dengan permainan, musik, dan sebagainya. (2) sumber belajar yang digunakan di sekolah tersebut adalah buku pegangan dari Depdiknas untuk kurikulum 2013. Dari buku pegangan yang dimiliki oleh siswa ternyata pembelajaran dirasa masih kurang untuk memahami materi functional text. (3) konsep pembelajaran pada kurikulum 2013 yang baru diterapkan adalah menggunakan paradigma student centered namun siswa masih sulit menerapkannya karena guru belum maksimal dalam memilih strategi penyampain bahan ajar. (4) penggunaan komputer untuk keperluan pembelajaran khususnya Bahasa Inggris masih belum digunakan oleh siswa maupun guru karena ketiadaan media sebagai penunjang pembelajaran khususnya functional text.

Beberapa data yang diperoleh dari hasil observasi dan wawancara dapat disimpulkan bahwa: (1) siswa memiliki karakteristik yang berbeda yang menginginkan pembelajaran Bahasa Inggris yang efektif yang sesuai dengan karakteristik siswa dan mata pelajaran. (2) Sumber belajar yang digunakan hanya buku pegangan dari kemendikbud kurikulum 2013. (3) Guru sudah mengajarkan materi functional text dengan baik namun masih sulit memberikan pemahaman kepada siswa 
karena metode yang digunakan belum cocok dengan materi functional text. (4) SMPN 3 Kalasan sudah memiliki laboratorium bahasa yang lengkap namun tidak dimanfaatkan dengan baik karena ketiadaan media pembelajaran.

Hasil data yang diperoleh dari pra survei selanjutnya dijadikan bahan pertimbangan dan masukan untuk mendesain serta mengembangkan produk multimedia pembelajaran Bahasa Inggris materi functional text dengan menggunakan metode/ pendekatan komunikatif sebagai untuk siswa SMP kelas VII. Dalam pengembangan produk multimedia ini menggunakan seperangkat software yang digunakan dalam pembuatan multimedia pembelajaran bahasa Inggris ini adalah Adobe Photoshop CS6, Macromedia Flash 9, Corel Draw dan software pendukung lainnya.

Pengembangan multimedia pembelajaran ini mengacu pada silabus kurikulum 2013 dan didesain dengan konsep instruksional sebagai media pembelajaran untuk memberikan solusi masalah pembelajaran Bahasa Inggris materi functional text. Secara garis besar produk multimedia pembelajaran hasil pengembangan meliputi: (1) petunjuk penggunaan program, yaitu untuk mengarahkan siswa cara menggunakan program multimedia pembelajaran. (2) Kompetensi Inti Kompetensi Dasar (KI KD), dan Indikator yaitu berisi tujuan pembelajaran yang harus dicapai oleh siswa. (3) Materi, yaitu berisi bahan pelajaran yang dipelajari siswa. Materi terdiri dari dua pokok bahasan yaitu instructions yang membahas tentang "notice, warning and caution", dan announcement, dan dalam menu materi juga dilengkapi dengan glossary sebagai panduan untuk siswa jika terdapat kesulitan dalam memahami kosa kata selama belajar, dan references yang mencantumkan sumber materi yang dimuat dalam multimedia pembelajaran. (d) evaluasi, yaitu berisi latihan soal-soal tentang materi functional text yang sudah dipelajari sebanyak 20 butir soal untuk mengetahui tingkat kompetensi yang telah dicapai oleh siswa. (e) games, yaitu memuat permainan yang terdiri dari dua permainan matching game dan announcement game yang tetap berhubungan dengan materi pelajaran agar siswa lebih termotivasi untuk mempelajari materi yang dianggap sulit. (f) Profil, berisi informasi tentang profil pengembang, pembimbing, ahli materi dan ahli media.

\section{Hasil Validasi Ahli Materi}

Pelaksanaan validasi dengan cara memberikan produk hasil pengembangan kepada validator untuk menilai masingmasing aspek serta memberikan penilaian dengan cara mengisi angket yang telah disediakan. Pada proses validasi, peneliti memperoleh data kuantitatif dan kualitatif yang sangat mendukung untuk pengembangan dan penyempurnaan produk multimedia pembelajaran yang dikembangkan.

Validasi ahli materi dilakukan untuk mengetahui kualitas produk multimedia pembelajaran ditinjau dari aspek materi. Aspek yang dinilai meliputi aspek kelayakan materi ajar denagn jumlah butir penilaian sebanyak 13 butir dan aspek pembelajaran sebanyak 14 butir. Validasi dilakukan dengan cara memberikan produk multimedia hasil pengembangan untuk kemudian dinilai oleh ahli materi dengan angket skala 5. Hasil penilaian ahli materi dapat dilihat pada Tabel 3.

Tabel 3. Rerata Skor Hasil Validasi Ahli Materi

\begin{tabular}{clcc}
\hline No & Aspek penilaian & Skor & Kriteria \\
\hline 1 & Aspek Pembelajaran & 4.14 & Baik \\
2 & Aspek Materi & 4.46 & Sangat Baik \\
& Jumlah & 8.6 & \\
& Rata-rata & 4.3 & Sangat Baik \\
\hline
\end{tabular}

Hasil Validasi Ahli Media

Validasi dilakukan untuk mengetahui kualitas bahan ajar ditinjau dari aspek media. Dua aspek yang dinilai yaitu aspek tampilan dengan jumlah butir penilaian sebanyak 11 butir dan aspek pemograman atau kegrafisan sebanyak 9 butir. Penilaian 
dengan menggunakan angket skala 5. Hasil penilaian ahli media dapat dilihat pada Tabel 4.

Tabel 4. Rekap Rerata Skor Hasil Validasi Ahli Media

\begin{tabular}{crrr}
\hline No & Aspek penilaian & Skor & Kriteria \\
\hline 1 & Aspek Tampilan & 4.54 & Sangat Baik \\
2 & Aspek Pemograman & 4.22 & Sangat Baik \\
& Jumlah & 8.76 & \\
& Rata-rata & 4.38 & Sangat Baik \\
\hline
\end{tabular}

Hasil Uji Beta/Siswa

Tujuan dilakukannya uji beta adalah untuk mengumpulkan informasi yang dapat digunakan untuk memperbaiki produk dalam revisi berikutnya. Jumlah siswa dalam uji beta berjumlah 31 siswa. Uji beta dilakukan dengan menunjukkan produk hasil pengembangan kepada siswa pada masing-masing monitor untuk dipelajari, selanjutnya siswa diminta untuk memberikan tanggapan mengenai kualitas produk dari tampilan tau penyajian media dan pembelajaran mengenai kemudahan materi yang disampaikan.

Data yang diperoleh dari hasil tanggapan siswa terhadap produk multimedia pembelajaran yang dikembangkan, kemudian dikonversikan ke dalam skala 5 . Hasil data uji beta pada kedua aspek tersebut di atas diketahui bahwa rerata skor penilaian sebesar 4.68 maka dikategorikan "sangat baik".

Terdapat 20 item penilaian yang keseluruhan mendapatkan penilaian sangat baik yaitu 12 aspek tampilan dan 7 aspek pembelajaran. Secara rinci aspek pembelajaran tersebut adalah: (a) kejelasan petunjuk belajar, (b) kemudahan dalam memahami materi, (c) kejelasan petunjuk mengerjakan latihan soal, (d) kejelasan dalam penguraian materi, (e) kesesuaian penggunaan Bahasa, (f) kesesuaian gambar dengan materi, (g) kecukupan pemberian soal latihan. Sedangkan rincian aspek tampilan adalah: (a) kemudahan pemakaian program, (b) kebebasan memilih menu materi untuk dipelajari, (c) ketepatan reaksi tombol, (d) kejelasan suara, (e) konsistensi letak tombol, (f) keterbacaan teks atau tulisan, (g) kemenarikan tampilan background dan animasi, (h) kemenarikan pemilihan warna, (i) kemenarikan pemilihan jenis dan ukuran huruf, (j) kemenarikan video, (k) kemenarikan tampilan gambar/contoh, (l) kemenarikan games yang disajikan.

Secara visual tampilan keseluruhan penilaian siswa pada uji beta terhadap multimedia pembelajaran bahasa Inggris dengan pendekatan komunikatif yang dikembangkan disajikan pada Gambar 2.

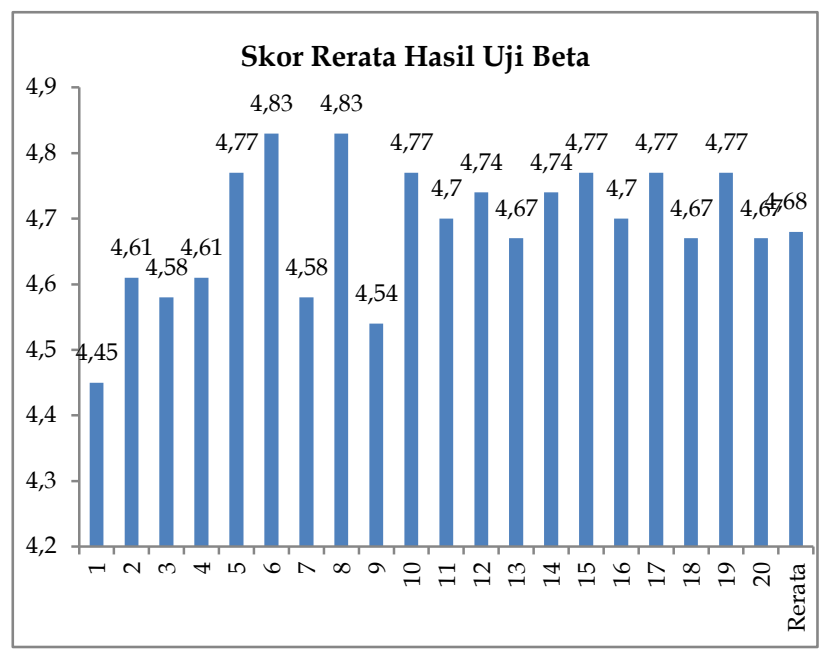

Gambar 2. Diagram Hasil Penilaian Uji Beta

Hasil Uji Kefektifan Produk

Uji coba keefektifan dilakukan untuk mengetahui keefektifan produk hasil pengembangan dalam pembelajaran bahasa Inggris materi functional text dengan melihat peningkatan gain skor dan ketuntasan belajar siswa. Ketuntasan belajar siswa dilihat dari sebelum dan setelah menggunakan produk multimedia pembelajaran dengan pendekatan komunikatif yang dikembangkan. Kriteria Ketuntasan Minimal (KKM) untuk mata pelajaran bahasa Inggris di SMP Negeri 3 Kalasan adalah 7,5.

Pembelajaran dengan menggunakan produk multimedia pembelajaran dengan pendekatan komunikatif ini dilakukan pada tangga 7 juni 2014 sampai dengan 19 Juli 2014 di SMP Negeri 3 Kalasan 
yang diikuti oleh 31 siswa. Penggunaan produk multimedia pembelajaran hasil pengembangan ini meliputi pelaksanaan pretes sebelum pembelajaran dimulai, kemudian dilanjutkan dengan pelaksanaan pembelajaran menggunakan produk multimedia pembelajaran dengan pendekatan komunikatif hasil dari pengembangan, dan diakhiri dengan pemberian post-test.

Adapun hasil dari siswa mengikuti pretes dan postes yang berjumlah 31 siswa, diketahui nilai tertinggi, nilai terendah, rerata dan selisih pretes-postes (N-Gain skor). Data tersebut disajikan pada Tabel 5.

Tabel 5. Perbandingan hasil pretes dan postes siswa

\begin{tabular}{llcccc}
\hline No & \multicolumn{1}{c}{ Nilai } & Pretes & Postes & $\begin{array}{c}\text { Indeks } \\
\text { Gain }\end{array}$ & Kriteria \\
\hline 1 & Nilai Terendah & 3 & 7 & 0.33 & Sedang \\
2 & Nilai Tertinggi & 8 & 10 & 1.00 & Tinggi \\
3 & Total & 200 & 282 & 24.04 & Tinggi \\
4 & Rata-rata & 6.45 & 9.09 & 0.74 & Tinggi \\
\hline
\end{tabular}

Selisih nilai pre test-post test N-gain skor secara visual disajikan pada Gambar 3.

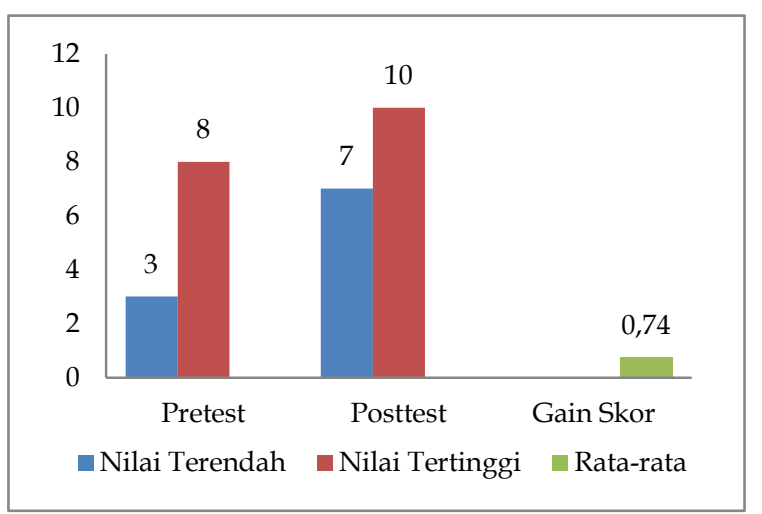

Gambar 3. Diagram Batang Hasil Uji Efektivitas

Berdasarkan gambar 3 dapat diketahui bahwa diperoleh nilai gain skor sebesar 0,74. Nilai tersebut berdasarkan klasifikasi nilai gain berada pada klasifikasi tinggi. Sedangkan ketuntasan belajar siswa mengacu pada KKM mata pelajaran bahasa Inggris di SMP N 3 kalasan yaitu $\geq 75$. Pada pretes sebelum siswa menggunakan produk multimedia pembelajaran terdapat $9(29.03 \%)$ siswa dinyatakan tuntas, sedangkan $22(70.96 \%)$ siswa dinyatakan tidak tuntas. Adapun hasil postes atau setelah siswa menggunakan multimedia pembelajaran bahasa Inggris terdapat 29 (93.5\%) siswa dinyatakan tuntas, sedangkan siswa yang dinyatakan tidak tuntas terdapat $2(6.45 \%)$ siswa. Adapun ketuntasan belajar siswa pada saat pretes dan postes dapat disajikan pada Gambar 4.

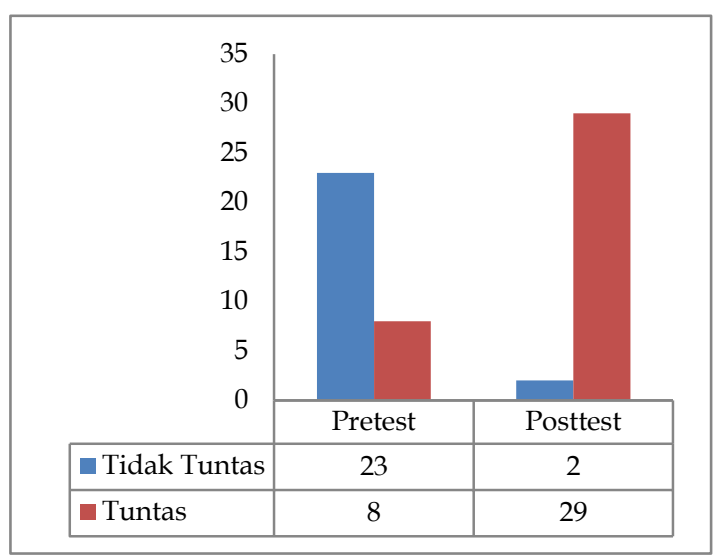

Gambar 4. Diagram Batang Ketuntasan Belajar Siswa

Berdasarkan data yang diperoleh, maka dapat disimpulkan bahwa produk multimedia pembelajaran Bahasa Inggris materi functional text bagi siswa kelas VII SMP N 3 Kalasan Yogyakarta dengan dengan pendekatan komunikatif adalah efektif digunakan sebagai media pembelajaran. Hal tersebut terbukti berdasarkan perolehan nilai gain skor serta ketuntasan belajar siswa setelah menggunakan produk multimedia pembelajaran bahasa Inggris hasil pengembangan. Hasil ini membuktikan bahwa produk multimedia pembelajaran yang dikembangkan efektif digunakan untuk sebagai pembelajaran Bahasa Inggris materi functional text.

Produk multimedia pembelajaran ini dikembangkan melalui beberapa tahap pengembangan, yaitu: perencanaan, desain, pengembangan serta dengan proses validasi dan revisi hingga akhirnya menghasilkan produk final. Tujuan dari penelitian ini yaitu untuk mengetahui kelayakan serta keefektifan produk multimedia pem- 
belajaran yang dikembangkan pada pembelajaran Bahasa Inggris materi functional text untuk siswa kelas VII SMP.

Bentuk akhir dari produk multimedia pembelajaran yang dikembangkan ini adalah software yang dikemas dalam bentuk $C D$ pembelajaran dengan pendekatan komunikatif. Produk multimedia pembelajaran dikembangkan menggunakan beberapa software diantaranya; Macromedia Flash 9, Corel Draw, dan Photoshop CS6.

Produk multimedia pembelajaran yang dikembangkan berjudul "Pengembangan Multimedia Pembelajaran Bahasa Inggris Materi Functional Text Bagi Siswa Kelas VII SMP N 3 Kalasan Yogyakarta" memuat beberapa konten mata pelajaran yang terdiri dari dua pokok bahasan utama yaitu: (1) instruction membahas notice, warning, dan caution yang semua berbicara tentang tanda-tanda atau simbol bahaya yang harus dihindari, dan (2) announcement membahas tentang bagaimana memahami sebuah pengumuman, membuat pengumuman dan cara menyampaikan pengumuman. Secara umum produk multimedia pembelajaran ini terdiri dari cover $\mathrm{CD}$, petunjuk penggunaan, kompetensi inti dan kompetensi dasar (KIKD), materi, evaluasi, games, dan profil.

Pengembangan produk multimedia pembelajaran ini didasarkan pada kurikulum 2013 yang sedang diterapkan pada sekolah tempat penelitian. Hal ini bertujuan agar produk media yang dikembangkan dapat terus berguna bagi siswa di sekolah tersebut, selain itu media dirancang untuk digunakan secara mandiri atau bersama yang dapat membantu siswa mudah memahami materi yang disajikan dengan baik.

Karakteristik dari produk multimedia pembelajaran Bahasa Inggris dengan pendekatan komunikatif ini memiliki keunggulan dibanding produk multimedia pembelajaran lain. Keunggulannya antara lain adalah: (1) penyajian produk ini dilengkapi dengan pemilihan video, audio, gambar-gambar functional text, teks, dan pemilihan huruf yang semuanya mempertimbangkan usia penggunanya sehingga menarik dan disenangi siswa. (2) Penggunaan programnya mudah yaitu hanya dengan memaksimalkan tombol yang ada, materi ini disusun sesuai urutan tingkat kesulitannya dan dilengkapi dengan evaluasi sehingga dapat meningkatkan daya retensi siswa. (3) Produk multimedia dilengkapi dengan games dan diberi umpan balik berupa reward sehingga siswa merasa senang dan terus ingin mencoba lagi. (4) Produk multimedia pembelajaran ini dikemas dengan cara yang sederhana yaitu dengan $\mathrm{CD}$ atau bahkan bisa dengan menggunakan flashdisk sehingga siswa dapat belajar dimana saja tanpa harus ada jaringan internet.

Produk multimedia ini dikembangkan sebagai media untuk membantu proses pembelajaran agar pembelajaran bisa lebih efektif, efisien, dan mudah untuk dipahami isinya. Selain itu multimedia pembelajaran ini juga dirancang untuk siswa agar tertarik belajar Bahasa Inggris dengan versi yang berbeda.

\section{Simpulan dan Saran}

Simpulan

Berdasarkan hasil penelitian dan pengembangan produk multimedia pembelajaran bahasa Inggris dengan pendekatan komunikatif ini, maka disimpulkan bahwa: pertama, produk ini layak digunakan dalam pembelajaran berdasarkan penilaian dari ahli materi, ahli media, dan siswa yang ditinjau dari kelayakan aspek materi, kelayakan aspek pembelajaran, kelayakan aspek tampilan, dan kelayakan pemograman atau kegrafisan. Dari keseluruhan uji kelayakan skor penilaian tersebut mendapatkan nilai dengan kategori Sangat Baik. Kedua, Produk multimedia pembelajaran Bahasa Inggris ini efektif untuk digunakan sebagai media pembelajaran. Hal tersebut terlihat dari hasil tes siswa dalam pemahamannya tentang materi functional text menggunakan produk multimedia pembelajaran dengan pendekatan 
komunikatif yang menunjukkan peningkatan hasil belajar dari nilai pretes ke nilai postes atau (N-Gain) skor sebesar 0.74 dengan kategori "sangat baik".

\section{Saran}

Saran bagi siswa agar pemanfaatan produk multimedia pembelajaran Bahasa Inggris pada materi functional text dapat efektif untuk pembelajaran, maka sebaiknya mengikuti saran-saran berikut: (1) siswa sebaiknya mencoba belajar mandiri secara individu atau mencari tahu (sesuai dengan konsep kurikulum 2013) dengan menggunakan multimedia pembelajaran bahasa Inggris yang sudah dikembangkan dengan baik, dan jika terdapat materi yang kurang dimengerti siswa dapat mendiskusikannya bersama teman ataupun dengan guru bidang studi, karena produk multimedia pembelajaran ini dirancang untuk dapat digunakan secara mandiri baik di rumah atau dimanapun. (2) Siswa sebaiknya banyak berlatih ataupun mengulang materi pelajaran dalam produk multimedia pembelajaran agar dapat lebih cepat menguasai dan mempraktekkan isi materi yang ada dalam kehidupan sehari-hari, serta dapat mengeksplor pemahamannya setelah menggunakan produk multimedia pembelajaran ini.

Bagi guru, pemanfaatan produk multimedia pembelajaran Bahasa Inggris yang telah dikembangkan ini akan efektif untuk pembelajaran jika digunakan dengan baik. Adapun saran pemanfaatan produk multimedia pembelajaran ini sebagai berikut: (1) guru sebaiknya menjelaskan kepada siswa bahwa belajar secara mandiri akan dapat lebih mudah memahami materi pelajaran yang ada dalam produk multimedia pembelajaran, karena siswa dapat mengulang kembali materi yang dianggap masih sulit untuk dipahami dengan waktu yang tidak terbatas serta siswa dapat mengukur kemampuannya sendiri. (2) Guru sebagai fasilitator dalam pembelajaran dapat memiliki banyak waktu untuk berdiskusi dengan siswa tentang hal-hal baru yang berkaitan dengan materi pelajaran karena telah terbantu dengan produk multimedia ini, jadi guru seharusnya dapat memaksimalkan penggunaannya dalam pembelajaran.

\section{Daftar Pustaka}

AECT. (2004). AECT definition and terminology committee document: the meanings of educational technology.

Alessi, S.M \& Trollip, S.R. (2001). Multimedia for learning method and development. Needham Heights: Allyn \& Bacon.

Djiwandono, S. (2011). Tes Bahasa pegangan bagi pengajar bahasa. Edisi kedua. Malang: PT. Indeks

Hake, R. R. (1998). Interactive-engagement vs traditional methods: A six-thousand-student survey of mechanics test data for introductory phsyics course. The American Journal of Physics Research 66, 64-74.

Iskandarwassid \& Sunendar, D. (2013). Strategi pembelajaran bahasa. Bandung: PT. Remaja Rosdakarya.

Ivers, K.S \& Barron, A.E. (2010). Multimedia project in education designing, producing and assessing. California: Libraries Unlimited.

Najjar, L. C. (1996). Multimedia information and learning. School of Psychology. Georgia Institute of Technology Atlanta, USA. Journal of Educational Multimedia and Hypermedia (1996) 5 (2), 129-150.

Supardi. (2011). Media pembelajaran. Yogyakarta: Kurnia Kalam Semesta. 